\title{
Macro Rain Water Harvesting Network to Estimate Annual Runoff at Koysinjaq (Koya) District, Kurdistan Region of Iraq
}

\author{
Saleh Zakaria ${ }^{1,2}$, Nadhir Al-Ansari ${ }^{2 *}$, Yaseen T. Mustafa ${ }^{3}$, M. D. J. Alshibli ${ }^{4}$, Sven Knutsson ${ }^{2}$ \\ ${ }^{1}$ Department of Water Resources Engineering, University of Mosul, Mosul, Iraq \\ ${ }^{2}$ Department of Civil, Environmental \& Natural Resources Engineering, Lulea University of Technology, Lulea, Sweden \\ ${ }^{3}$ University of Zakho, Duhok, Iraq \\ ${ }^{4}$ Ministry of Water Resources, Baghdad, Iraq \\ Email: saleh.zakaria@ltu.se, "nadhir.alansari@ltu.se, Y.T.Mustafa@uoz-krg.org, Sven.Knutsson@ltu.se
}

Received October 7, 2013; revised November 7, 2013; accepted November 14, 2013

Copyright (c) 2013 Saleh Zakaria et al. This is an open access article distributed under the Creative Commons Attribution License, which permits unrestricted use, distribution, and reproduction in any medium, provided the original work is properly cited.

\begin{abstract}
Macro rainwater harvesting techniques (Macro RWH) are getting more popular to overcome the problem of water scarcity in arid and semi-arid areas. Iraq is experiencing serious water shortage problem now despite of the presence of Tigris and Euphrates Rivers. RWH can help to overcome this problem. In this research, RWH was applied in Koya City in its districts, North West Iraq. Twenty-two basins were identified as the catchment area for the application of RWH technique. Watershed modeling system (WMS), based on Soil Conservation Service-curve number (SCS-CN) method, was applied to calculate direct runoff from individual daily rain storm using average annual rainfall records of the area. Two consecutive adjustments for the curve number were considered. The first was for the antecedent moisture condition (AMC) and the second was for the slope. These adjustments increased the total resultant harvested runoff up to 79.402 $\times 10^{6} \mathrm{~m}^{3}$. The average percentage of increase of harvested runoff volume reached $9.28 \%$. This implies that water allocation is of the order of 2000 cubic meter per capita per year. This quantity of water will definitely help to develop the area.
\end{abstract}

Keywords: Macro Rainwater Harvesting; Koysinjaq; Kurdistan Region; Iraq

\section{Introduction}

The Middle East and North Africa (MENA) region is characterized by its arid to semiarid climate where the average annual rainfall does not exceed $166 \mathrm{~mm}$ [1]. Iraq is part of the MENA region and was not facing any water shortages till the 1970s. After that, the dams built on the upper parts of the Tigris and Euphrates Rivers in Syria and Turkey plus the effect of global warming had changed the situation $[2,3]$. In evaluating Iraqi water resources issue, the future predictions suggest more shortages [4,5]. It is expected that Tigris and Euphrates Rivers will be completely dry by 2040 [6].

Furthermore rainfall is not sufficient to support economic crop yield during rainy seasons without irrigation. The average annual rainfall in Iraq is ranging from 154 to $216 \mathrm{~mm} /$ year $[7,8]$. It should be mentioned that the rain-

${ }^{*}$ Corresponding author. fall widely varies from north to south and from west to east of Iraq, where it reached more than $1000 \mathrm{~mm}$ within the mountains at the north, $150 \mathrm{~mm}$ within the western desert to about $200 \mathrm{~mm}$ at the eastern part of the country. In many regions having limited water resources, including surface or sub-surface water, the available water is no longer sufficient to cover the ever increasing water demand [9]. For this reason, farmers are using groundwater in irrigation to cover the shortages due to low rainfall. As a consequence, excessive pumping of ground water was practiced, which led to falling of water tables in different parts of the Middle East $[10,11]$. Thus water scarcity will be one of the major challenges facing the world during this century [12] and the Middle East in particular $[13,14]$.

The limitation of water sources, rising water demand in addition to mismanagement water resources, in Developing World, is contributing to the water scarcity 
problem [12].

Water resource management is becoming one of the most important economic and social issues in this century [15]. Therefore, the situation requires a new technique and method for conservation and judicious water [12].

Some countries of the MENA region had provided alternative non-traditional water sources, such as rainwater harvesting (RWH), to overcome the water scarcity problem [16-18].

In this research, RWH technique is to be used to overcome the water shortage problem in Koya area, northeast of Iraq. RWH has different definitions [19]. Boers and Ben-Asher, (1982) [20] gave a more specific definition of RWH with specific details, where they defined RWH as "a method for inducing, collecting, storing, and conserving local surface runoff for agriculture in arid and semi-arid regions". They explained that the RWH includes several processes which start dealing with the catchment area to guarantee the stream runoff flow then to direct it by the natural drainages that distributed on the catchment area to the target storage location (a surface reservoir or a soil profile). Furthermore, they specified the aim of this process for agriculture purposes. Finkel and Finkel, (1986) [21] defined RWH as "the collection of runoff and its use for the irrigation of crops, pastures and trees, and for livestock consumption”. Siegert, (1994) [22] defined RWH as "the collection of runoff for its productive use".

Prinz, (2000) [12] summarized six different forms of RWH according to the location, function and size of catchment area as follows: 1) Roof Top RWH, 2) RWH for Animal Consumption, 3) Inter-Row RWH, 4) Micro-catchment RWH, 5) Medium-sized Catchment RWH and 6) Large Catchment RWH (Macro-catchment).

For the annual rainfall between 100 and $700 \mathrm{~mm}$, water harvesting might provide new source of water which is not readily available or too costly [23].

The productivity of the rainwater can be significantly improved by applying a specific technique such as Macro RWH, based on availability of a surface reservoir. By this technique, the excess rainwater (runoff) is stored in small reservoirs of small dams with different sizes to be supplied later when required [24-27].

RWH can only increase the availability of rainwater to the user but not its amount, certainly by concentrating the excess rainwater (runoff) in a limited area which increases the potential risk of erosion, so suitable measures must be taken to prevent soil erosion [28].

RWH systems had proven to be an effective technique in different regions to achieve new water source that can be used for several purposes, furthermore, in comparison with pumping water, water harvesting saves energy and maintenance costs [23].
Macro catchment RWH systems gave good results at different parts of the world and led to an increase in crop production [29-31]. Furthermore, studies by some researchers (e.g. Bruins et al., 1986; Fox and Rockstrom, 2003; Hatibu et al., 2003; Motsi et al., 2004; Barron and Okwach, 2005; Liu et al., 2005 [32-37]) were conducted in different parts of Africa which indicated that rainwater harvesting is working to reduce the risk of drought and increase agricultural production. For the above studies, RWH generates a new source of water where water is not readily available [38]. Hatibu and Mahoo, (1999) [39], indicate that Macro RWH is a system that involves the collection of runoff from large areas that are ranging from 0.1 ha to thousands of hectares with slopes ranging from $5 \%$ to $50 \%$. This system is used in Tanzania with storage of water outside the cropped basin for later use.

Most of the techniques of water harvesting systems focus on capturing more water [40], for Macro RWH, however, it is the capture rainfall that falls outside the farmland [41]. Effective management of RWH becomes more interesting phase of water resources management strategies in most countries that are suffering from the problem of water scarcity.

RWH is the use of lost runoff water and it proved to be one of the most effective methods to overcome water shortages in arid and semi-arid regions [19-22,27,28]. In addition, Macro RWH significantly improves the productivity and it increases the availability of rainwater to the user and it was proved that this system gave very good results $[24,29,30]$. In view of the above, this method was applied in Koya and its districts.

This research is treating RWH for the whole area that is composed of twenty-two selected sites. It is anticipated to establish a network of Macro RWH distributed around Koya City, Kurdistan region of Iraq in order to estimate the annual amount of runoff that could be harvested and used. Furthermore, this type of technique and the modified curve numbers had been used for the first time in this area.

\section{Methodology}

Dams are to be built to harvest the excess rainfall (runoff) for a given area. To achieve this goal then it is necessary to identify the sites of the dams. This can be done using Digital Elevation Model (DEM) of the study area with Global Mapper model. Certainly the dam site will be located on runoff stream (main trajectory) considering minimum dam's cross section to minimize the constructions cost. Watershed modeling system (WMS) was used with Konya's DEM. The model was applied using the information obtained from land use map, soil type and rainfall data, for all individual selected basins. The runoff volumes were estimated based on Soil Conservation Ser- 
vice-curve number (SCS-CN) method. The main steps that should be follow can be summarized as follow: Identification each of the drainage boundaries of the selected basins within the study area, the hydrologic soil group classification to determine the runoff curve number for a given soil kind using the tables of SCS, 1972. Then land use map is usually used to identify the curve number $(\mathrm{CN})$ values for each selected basin. The time of concentration for selected basins is estimated, and the daily rainfall depth is to be determined considering single rainfall storm on the study area. Then the suitable storm type (I, 24-hour Storm) should be chosen. The hydrograph time increments of six minutes or less are to be set, and the volumes of runoff for the selected basins are to be calculated.

Furthermore, the SCS curve number method based on the relationships between precipitation and runoff expressed as:

$$
\begin{gathered}
Q=\frac{(p-0.2 S)^{2}}{P+0.8 S} \text { if } p>0.2 S \\
Q=0 \text { if } p \leq 0.2 S \\
Q=\left(\frac{1000}{C N}-10\right) * 25.4
\end{gathered}
$$

where:

$Q=$ the direct runoff or rainfall excess (mm).

$P=$ the storm rainfall (mm).

$S=$ the maximum potential soil water retention $(\mathrm{mm})$, and $C N=$ the curve number (dimensionless).

With SCS-CN method, the soil was classified into four hydrological soil groups A, B, C and D considering the basin wetness index i.e. the antecedent moisture condition (AMC) which had been classified into three classes AMC I, AMC II and AMC III, representing dry, average and wet conditions. In order to specify each class, the antecedent rainfall amount of five-day and season category (dormant and growing seasons) were considered.

For the Soil Conservation Service, 1972 (SCS-CN) method, the tabulated curve number is equal to $\mathrm{CN}_{\mathrm{II}}$, for average (normal) conditions, and modified for dry and wet conditions, as explained by Chow [42] through the following equations:

$$
\begin{gathered}
C N_{I}=\frac{4.2 * C N_{I I}}{10-0.058 * C N_{I I}} \\
C N_{I I I}=\frac{23 * C N_{I I}}{10+0.13 * C N_{I I}}
\end{gathered}
$$

In which: $C N_{I}=$ Curve number for dry condition.

$C N_{\text {III }}=$ Curve number for wet condition.

Williams [43] developed an equation to adjust the curve number to a different slope $[44,45]$ :

$$
\begin{aligned}
& {\left[C N_{I I}\right]_{S L P}=\frac{\left(C N_{I I I}-C N_{I I}\right)}{3}} \\
& *[1-2 * \exp (-13.86 * S L p)]+C N_{I I}
\end{aligned}
$$

where:

$\left[C N_{I I}\right]_{S L P}=$ the curve number for average condition adjusted for the slope.

$S L P=$ the average fraction slope of the basin.

\subsection{Study Area}

Koysinjaq (Koya) is one of the most important districts of Erbil Governorate at Kurdistan region of Iraq (Figure 1), which is witnessing a state of rapid growth and development. According to the Iraqi statistics of 1987 the population of Koysanjaq is about 39,484 people.

Koya districts have a very important geographical location where it connects three provinces of Iraq which are Sulaimaniyah, Kirkuk and Erbil. Koya district consists mainly of five parts which are TaqTaq, Ashti, Shoresh, Sktan and Sekrkan. The district is bordered from the east and south by lesser Zab River, and from the northeast by Hebat Sultan mountain, from the west by Bawage Mountain. The mountainous area is located north Koysinjaq, while at the south and southwest, a fertility plain extends to the border of Erbil with Kirkuk city, which represents the historical alluvial plain of the Tigris River. Rainwater is the main source for agricultural processes in the area in addition to the ground water.

The soil texture in the mountainous regions is sandy clay, loam silt or loam clay sand, with an average depth of $130 \mathrm{~cm}$. While the soils texture of the plain regions consists of loam clay sand, loam silt and silt clay, with an average depth of $140 \mathrm{~cm}$ [46]. Buringh (1960) [47] described the soil of study area (Figure 2) and refer that soil color varies between light yellow to dark brown at north and between brown and dark brown at the plain regions as a shallow phase over Bakhtiary gravel.

\subsection{Koya Rainfall}

Rainfall records at Koya station of the period 2002-2003 to 2010-2011 were used in this research. Two seasons (2007-2008 and 2008-2009) where neglected due to missing data. These records show that the rainy season extends from November to May. The annual rainfall varies from one season to the other. The total rainfall reached minimum value of $433.9 \mathrm{~mm}$ during the season 2005-2006, while it reached maximum value of 989.2 mm during the season 2003-2004 (Figure 3).

The average rainfall depth for the study period reached $650.2 \mathrm{~mm}$ which is very close to that of the season 20092010.

Figure 4, shows that the fourteen rain storms with appropriate antecedent moisture as recommended by 


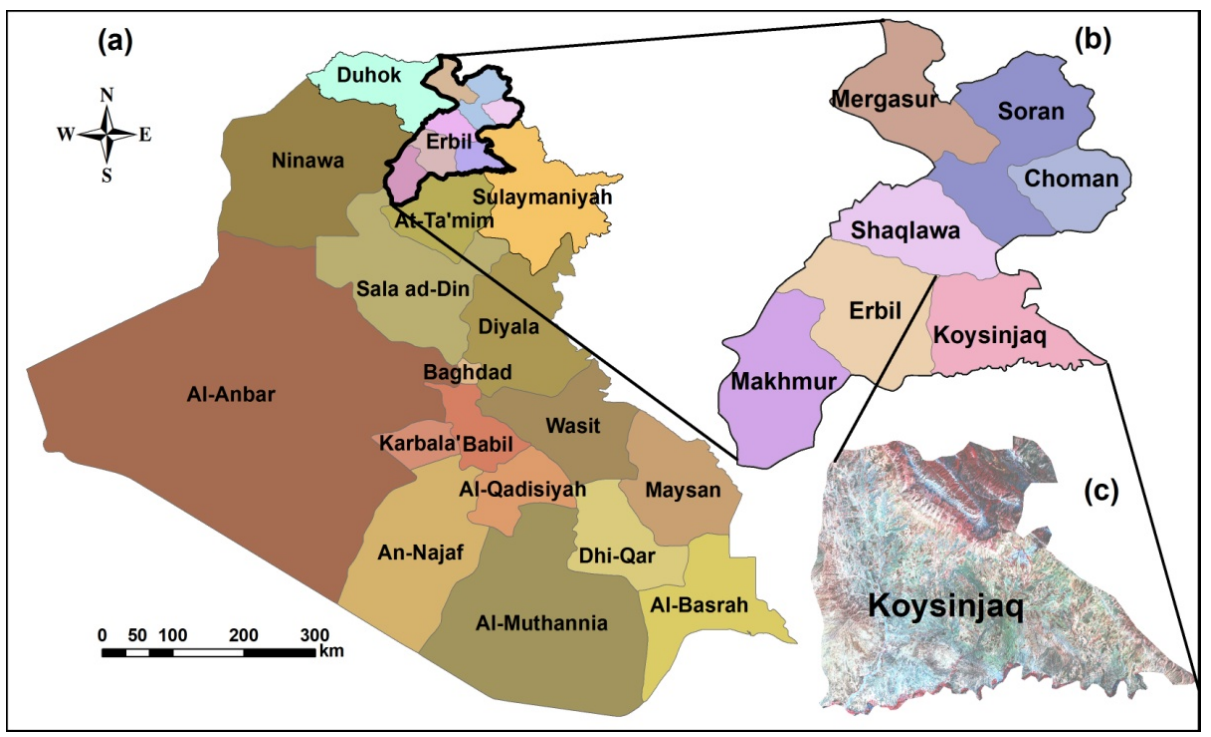

Figure 1. Map of Iraq (a); Erbil governorate (b); Location of study area (Koya) (c).

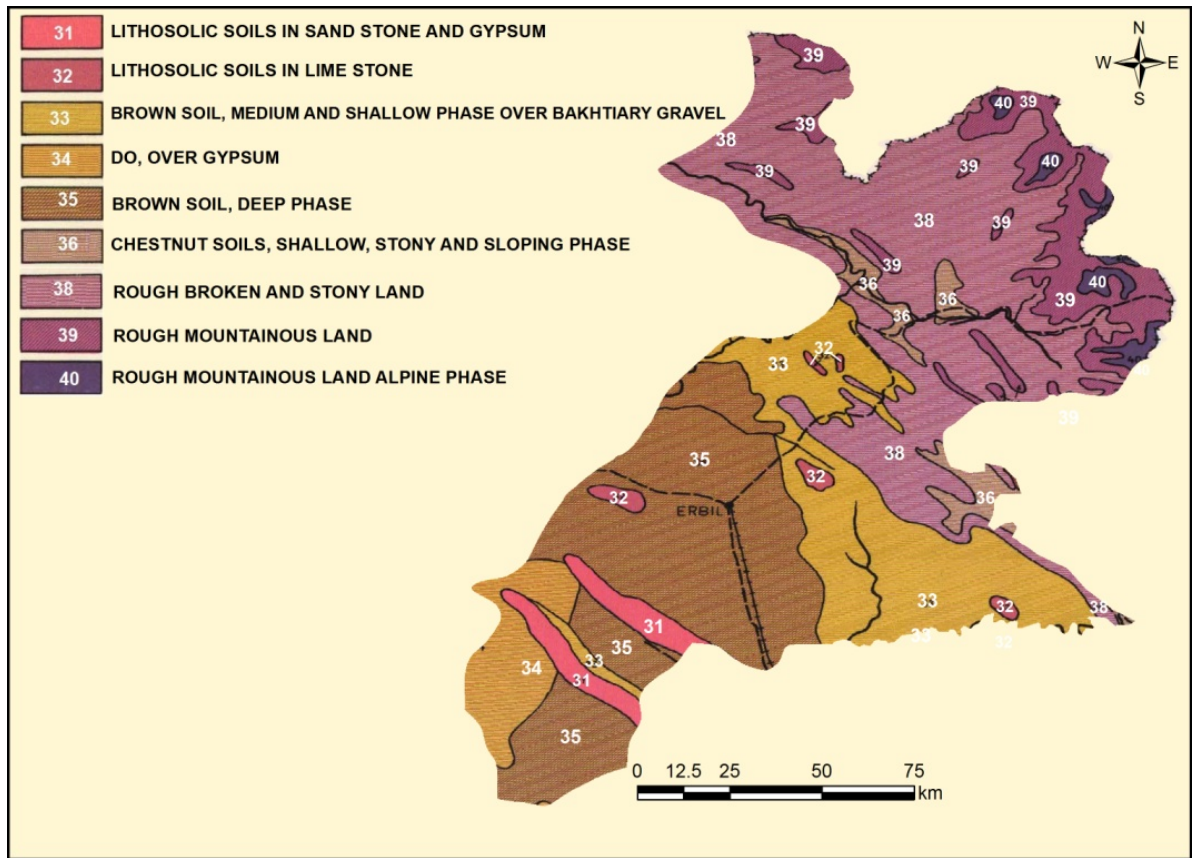

Figure 2. Soil map of Erbil Government as described by Buringh 1960, source [48].

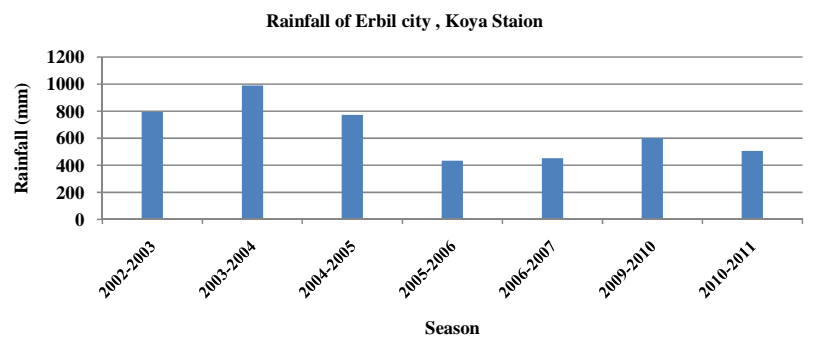

- Rainfall of Erbil city , Koya Staion

Figure 3. Annual rainfall depths on Koya area for the period (2002-2011), source [48].

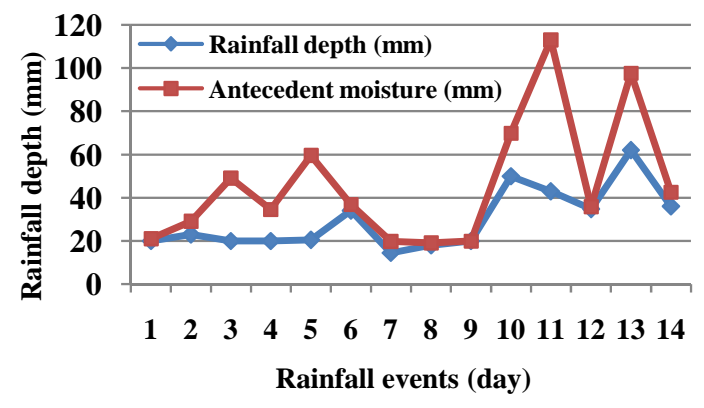

Figure 4. Rainfall depth with corresponding antecedent moisture for the season (2009-2010). 
SCS-CN method for the season 2009-2010.

The rainfall season 2009-2010 starts at the first of November. The season includes fifty-six of daily rain storms that were distributed along 210. Fourteen of these rainfall storms had produced runoff events. Of these, four storms were under average conditions and ten under wet conditions. These conditions were specified according to the antecedent moisture classes (AMC) for the SCS-CN method.

The study has been focused on the above fourteen rain storms that each has exceeded $12.5 \mathrm{~mm}$ in depth and produced runoff. Sequences were given to the rain storms according to the time of occurrence.

\subsection{Land Use/Land Cover}

Figure 5 shows that land use land cover (LULC) map for Koya district with twenty-two selected basins for rainwater harvesting. LULC map was classified into five classes (type) in the study area. They were building up, vegetation, bare soil, rock, and water. The basins were numbered starting from the far north of Koya city in an anticlockwise direction.

\subsection{Curve Number}

The weighted average CN values for twenty-two selected basins at Koya District were estimated depending on area of specific land use land cover as a percent of total basin area and calibrated based on antecedent moisture condi- tion (AMC) for dry, average, and wet conditions depending on the total antecedent rainfall depth of five days as formulated by Soil Conservation Service-curve number (SCS-CN) method. The properties of the selected basins at Koya District were estimated (Table 1).

Then CN values were adjusted for slope using Williams [43] formula for each basin (Table 2).

\section{Results and Discussion}

Data elevation modeling (DEM) of Koya districts of Kurdistan region of Iraq, was used to identify the suitable sites of dams in order to harvested the exceed rainwater (runoff) from the catchments area. Twenty-two basins were selected for rainwater harvesting.

It should be noted that any basin that was not representing a continuous hydrological unit was excluded. In other word, the runoff should be continuously drained within its catchment area to the outlet where the harvested dams are located.

The harvested runoff from the individual selected basins can be stored at the outlet of each basin to conform individual reservoirs of different capacities using harvested dams. The harvested runoff volumes were estimated using WMS.

To simplify the analysis of the harvested runoff, the twenty-two selected basins at Koya District were divided into four groups of basins according to the geographiclocation as follows: At the north, group number one in

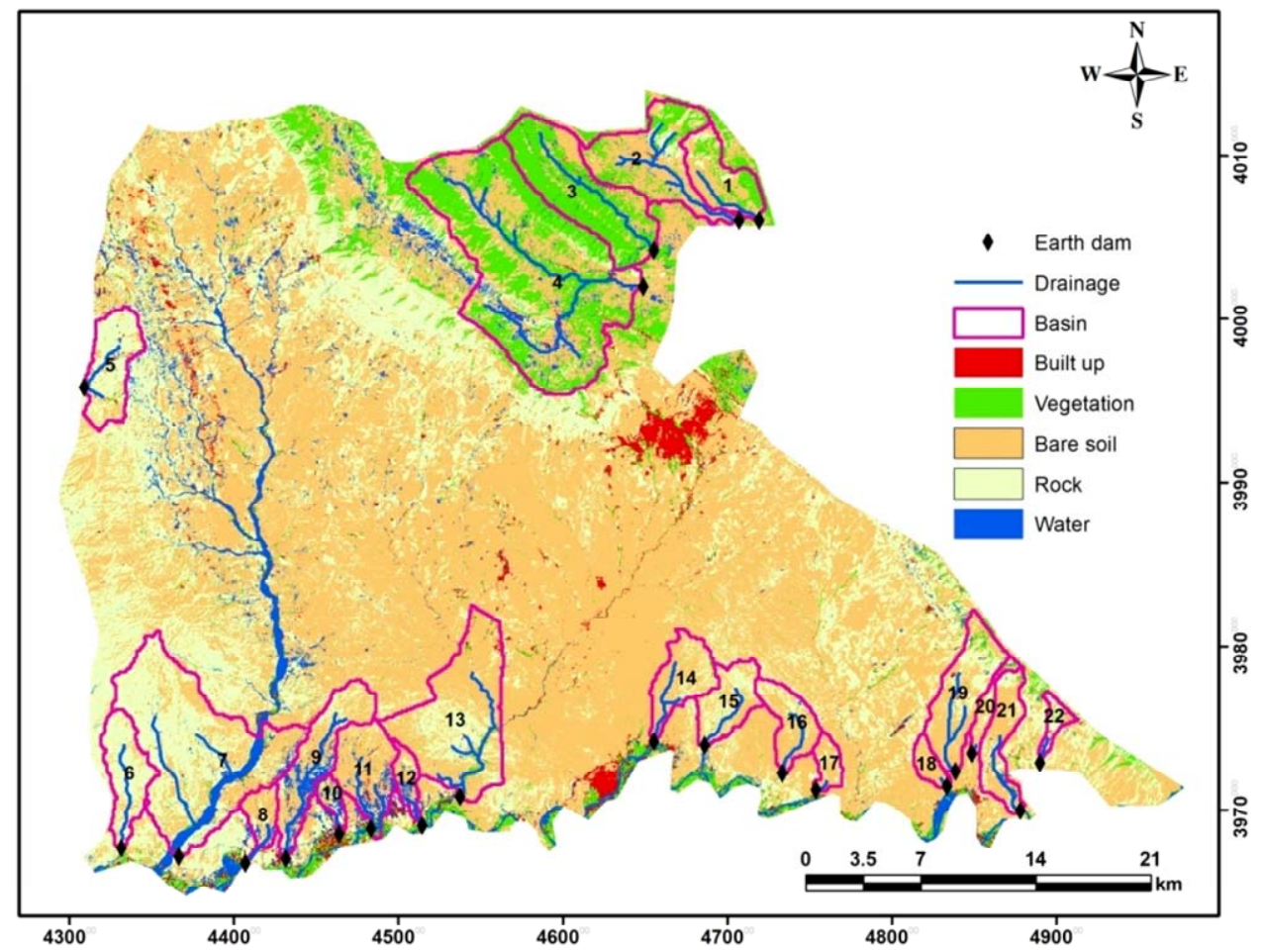

Figure 5. LULC map for Koya districts with twenty-two selected basins for rainwater harvesting, source [48]. 
Runoff before adjesment $\mathrm{CN}$ for slope

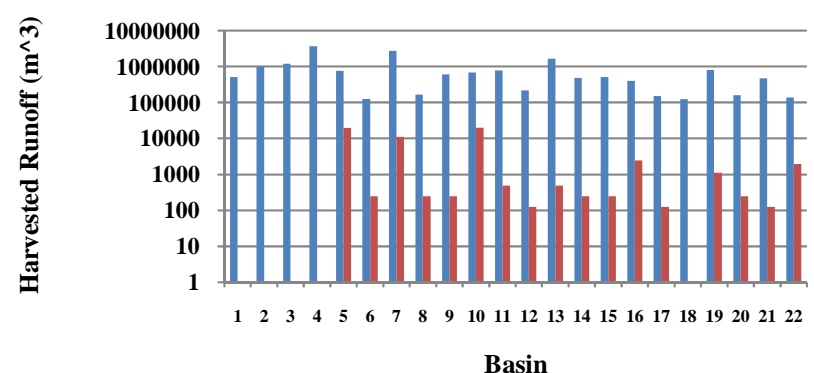

- Runoff for Maximum Rain Storm (62.0) mm

- Runoff for Minimum Rain Storm (14.5) mm
Runoff after adjesment CN for slope

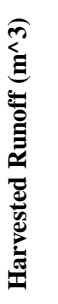

匹unoff for Maximum Rain Storm (62.0) mm - Runoff for Minimum Rain Storm (14.5) mm

Figure 6. Harvested runoff volumes for maximum and minimum rain storms, before and after adjustment Curve Number for the slope for the 22 basins.

Table 1. Properties of twenty-two selected basins at Koya districts.

\begin{tabular}{|c|c|c|c|c|c|c|c|}
\hline Group & Basins & Area $\left(\mathbf{K m}^{2}\right)$ & Slope $(\mathbf{m} / \mathbf{m})$ & Length (m) & Elevation (m) & Basin area ratio & $\%$ \\
\hline \multirow{5}{*}{1} & 1 & 30.95 & 0.15 & 29095.29 & 684.3 & 6.26 & \\
\hline & 2 & 15.51 & 0.14 & 6771.437 & 740.7 & 3.14 & \\
\hline & 3 & 37.68 & 0.28 & 26771.5 & 845.8 & 7.63 & \\
\hline & 4 & 111.63 & 0.19 & 15822.17 & 913.8 & 22.59 & \\
\hline & 5 & 17.15 & 0.08 & 5552.237 & 740.7 & 3.47 & \\
\hline \multirow{8}{*}{2} & 6 & 15.57 & 0.08 & 8464.906 & 554.1 & 3.15 & \\
\hline & 7 & 72.99 & 0.08 & 13505.08 & 426.4 & 14.77 & \\
\hline & 8 & 6.22 & 0.06 & 5245.913 & 361.5 & 1.26 & \\
\hline & 9 & 22.14 & 0.08 & 11863.12 & 436.8 & 4.48 & \\
\hline & 10 & 3.47 & 0.06 & 630.3264 & 367.3 & 0.70 & \\
\hline & 11 & 17.95 & 0.09 & 6697.066 & 407.2 & 3.63 & \\
\hline & 12 & 4.90 & 0.08 & 5648.858 & 413.6 & 0.99 & \\
\hline & 13 & 47.40 & 0.09 & 9330.842 & 407.5 & 9.59 & \\
\hline \multirow{4}{*}{3} & 14 & 14.12 & 0.09 & 7112.508 & 518.5 & 2.86 & \\
\hline & 15 & 13.13 & 0.14 & 6021.934 & 584.9 & 2.66 & \\
\hline & 16 & 11.53 & 0.11 & 5957.011 & 531.9 & 2.33 & \\
\hline & 17 & 4.45 & 0.08 & 3552.444 & 472.4 & 0.90 & \\
\hline \multirow{5}{*}{4} & 18 & 3.86 & 0.09 & 3534.156 & 447.4 & 0.78 & \\
\hline & 19 & 22.14 & 0.12 & 9910.267 & 634.3 & 4.48 & \\
\hline & 20 & 4.43 & 0.10 & 6418.783 & 632.8 & 0.90 & \\
\hline & 21 & 13.55 & 0.12 & 8739.835 & 548.9 & 2.74 & \\
\hline & 22 & 3.34 & 0.20 & 4392.473 & 711.4 & 0.68 & \\
\hline
\end{tabular}

cludes the basins 1B, 2B, 3B, 4B, and 5B. Southwest of Koya, group number two includes 6B, 7B, 8B, 9B, 10B, $11 \mathrm{~B}, 12 \mathrm{~B}$ and 13B. At the middle south of Koya district, group number three includes 14B, 15B, 16B, and 17B. At the southeast, group number four includes 18B, 19B, 20B, 21B, and 22B. 
Table 2. Curve number (CN) values before and after adjustment for slope for the twenty-two selected basins at Koya districts.

\begin{tabular}{|c|c|c|c|c|c|c|}
\hline \multicolumn{4}{|c|}{ Before adjustment CN for slope } & \multicolumn{3}{|c|}{ After adjustment $\mathrm{CN}$ for slope } \\
\hline Basins & Normal & dry & wet & Normal & dry & wet \\
\hline 1 & 76.0 & 57.1 & 87.9 & 78.97 & 61.20 & 89.63 \\
\hline 2 & 75.9 & 56.9 & 87.8 & 78.73 & 60.85 & 89.49 \\
\hline 3 & 75.1 & 55.9 & 87.4 & 79.03 & 61.28 & 89.66 \\
\hline 4 & 76.0 & 57.1 & 87.9 & 79.40 & 61.81 & 89.86 \\
\hline 5 & 86.5 & 73.0 & 93.7 & 87.32 & 74.30 & 94.06 \\
\hline 6 & 87.0 & 73.7 & 93.9 & 87.78 & 75.11 & 94.29 \\
\hline 7 & 80.7 & 63.6 & 90.6 & 81.82 & 65.40 & 91.19 \\
\hline 8 & 78.4 & 60.3 & 89.3 & 78.87 & 61.05 & 89.57 \\
\hline 9 & 78.5 & 60.5 & 89.4 & 79.74 & 62.30 & 90.05 \\
\hline 10 & 79.6 & 62.2 & 90.0 & 80.05 & 62.76 & 90.22 \\
\hline 11 & 77.1 & 58.6 & 88.6 & 78.73 & 60.86 & 89.49 \\
\hline 12 & 77.1 & 58.6 & 88.6 & 78.40 & 60.39 & 89.30 \\
\hline 13 & 78.0 & 59.8 & 89.1 & 79.57 & 62.07 & 89.96 \\
\hline 14 & 77.7 & 59.4 & 88.9 & 79.29 & 61.65 & 89.80 \\
\hline 15 & 81.1 & 64.3 & 90.8 & 83.40 & 67.85 & 92.04 \\
\hline 16 & 78.4 & 60.4 & 89.3 & 80.45 & 63.35 & 90.44 \\
\hline 17 & 77.5 & 59.1 & 88.8 & 78.78 & 60.93 & 89.52 \\
\hline 18 & 75.4 & 56.3 & 87.6 & 77.13 & 58.62 & 88.58 \\
\hline 19 & 79.1 & 61.3 & 89.7 & 81.29 & 64.61 & 90.91 \\
\hline 20 & 79.1 & 61.3 & 89.7 & 80.87 & 63.96 & 90.67 \\
\hline 21 & 77.9 & 59.6 & 89.0 & 80.20 & 62.98 & 90.31 \\
\hline 22 & 84.0 & 68.8 & 92.4 & 86.45 & 72.82 & 93.62 \\
\hline
\end{tabular}

The area of the twenty-two selected basins ranged 3.34 - $111.63 \mathrm{~km}^{2}$ and the total area of the selected basins is $494.11 \mathrm{~km}^{2}$. Basins slope ranged between $6 \%-28 \%$, their length ranged between $0.63-29.09 \mathrm{~km}$, and their elevation ranged between 361.5 - $913.8 \mathrm{~m}$ (Table 1).

In spite of the fact, that, most of the selected basins are small in their areas, but their runoff is of relatively good quantity. However, the area is not the only decisive factor to control the quantity of runoff, although it is one of the important factor to maximize the volume of runoff in the basin, but still other factors like $\mathrm{CN}$ values (which represent the hydraulic conditions of the selected land) and the slope are more sensitive to reflect their strong impact on the composition of runoff. It is very difficult to separate the effect of the variables involved (e.g. area, slop and $\mathrm{CN}$ ) on the produced runoff at a given basin. However, these factors in addition to the rainfall pattern play an important role together to form the harvested runoff. In fact, rainfall has two effects, the first is its amount, so as far as there is an increase in rainfall depth that will help to increased harvested runoff amount. Secondly, by its distribution i.e. when the span time (between two subsequent rain storms) increases or decreases.

A comparison of runoff volumes for all sloped basins, under same condition, may explain the effect of rainfall depth, and basins' slop. The runoff was always achieved in maximum volumes under maximum rain storm (62.0 $\mathrm{mm}$ ) and minimum volume under minimum rain storm (14.5 mm) also the runoff increased after adjusted CN for slope (Figure 6).

It should be noted that, the weak rainfall storm (that does not produce runoff) is very important for estimating the $\mathrm{CN}$ values. The weak rainfall effects directly the antecedent moisture condition (AMC) and then the corresponding value of $\mathrm{CN}$ and change its value from average to wet condition or vice versa and this is very sensitive for runoff calculations [48].

Figures 7 and 8 show the results of harvested runoff by all groups of the basins. The harvested runoff volume, 

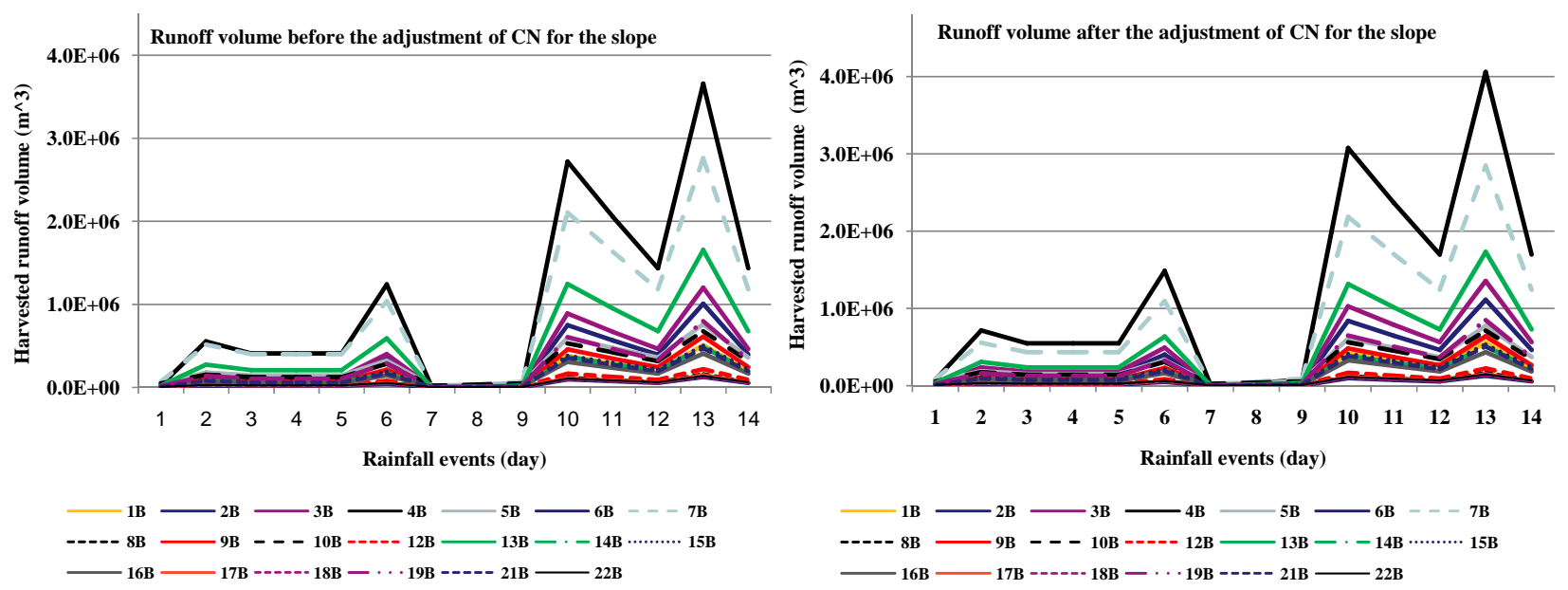

Figure 7. Seasonal harvested runoff through fourteen rain storms events for the selected basins.

without adjusted CN for the slope, reached up to 28.618, 29.543, 6.421 and 7.005 million cubic meters for the group 1 to 4 respectively. With adjusted CN for the slope, the harvested runoff reached up to $33.217,31.388,7.031$, and 7.766 million cubic meters for the group 1 to 4 respectively. The results of total harvested runoff by all 22 basins were 71.586 and 79.402 million cubic meters before and after the adjustment of $\mathrm{CN}$ for the slope respectively. Within the selected basins, the maximum harvested runoff achieved at basin 4B were 14.373 and 16.941 million cubic meters and minimum at basin $18 \mathrm{~B}$ were 0.485 and 0.530 million cubic meters before and after the adjustment of $\mathrm{CN}$ for the slope respectively.

Figure 7 shows that the comparison of harvested runoff volumes between two cases (before and after) the adjustment $\mathrm{CN}$ for the slope. The comparison shows that the runoff patterns for all fourteen rainstorms that produced runoff.

The results indicate that there was an increase in harvested runoff volume due to the adjustment of CN for the slope. The maximum, minimum, and average increase of harvested runoff volume reached $20.81 \%, 1.92 \%$, and $9.28 \%$ respectively.

Figure 8 shows that the annual harvested runoff contribution of each basin as a volume with its percentage of total harvested runoff volume at total Koya districts considering the adjustment of $\mathrm{CN}$ for the slope, where the maximum harvested runoff was achieved at basin 4B (16.941) million cubic meters represented $21.3 \%$ of total annual harvested runoff volume, while the minimum harvested runoff was achieved at basin 18B (0.530) million cubic meters represented $0.7 \%$ of total annual harvested runoff volume.

The total quantity of water (79.402 million cubic meters) if harvested will give an annual allocation of about 2000 cubic meter per capita. In addition, hundreds of square kilometers of land can be irrigated using the har

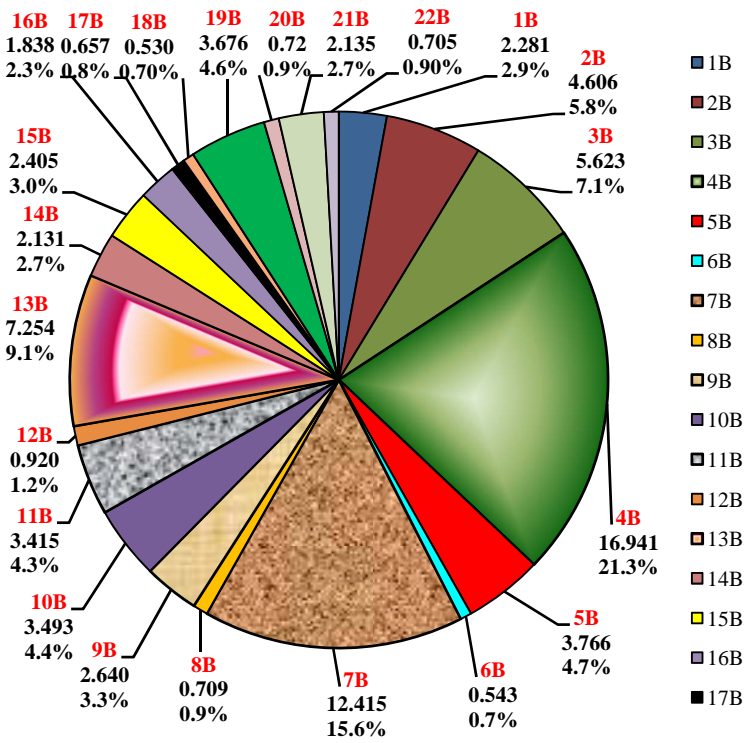

Figure 8. Annual harvested runoff that contributed by each basin as a volume $\left(\times 10^{6} \mathrm{~m}^{3}\right)$ with its percentage of total annual harvested runoff at total Koya districts, considering the adjustment $\mathrm{CN}$ for the slope.

vested water.

\section{Conclusions}

Koya City and its districts, at Kurdistan region of Iraq, are rapidly developing under conditions of limited water availability. All future expectations indicate more severe shortages in water resources in Iraq. It is believed that rain water harvesting technique can help a large extent to overcome this situation. The results obtained with water harvesting technique using the average annual rainfall showed that a minimum of $79.402 \times 10^{6}$ cubic meters of water can be harvested annually. This suggests that the allocation per capita per year will be about 2000 cubic 
meters. This will definitely help to develop the agricultural and industrial activities in the area.

The results indicated that there was an increase in harvested runoff volume due to the adjustment of CN for the slope. The maximum, minimum, and average percentage of increase of harvested runoff volume reached $20.81 \%, 1.92 \%$, and $9.28 \%$ respectively.

The results show that Koya district has the ability to produce good amount of annual volume of runoff that reached, but unfortunately, most of these quantities are lost without any benefit.

\section{Acknowledgements}

The authors would like to express their sincere thanks to the Ministry of Higher Education and Scientific Research, Baghdad, Iraq; Mosul university, Mosul, Iraq for their support. Deep thanks to Mrs. Semia Ben Ali Saadaoui of the UNESCO-Iraq for her encouragement and support. The research presented has been financially supported by Luleå University of Technology, Sweden and by "Swedish Hydropower Centre-SVC" established by the Swedish Energy Agency, Elforsk and Svenska Kraftnät together with Luleå University of Technology, The Royal Institute of Technology, Chalmers University of Technology and Uppsala University. Their support is highly appreciated.

\section{REFERENCES}

[1] N. A. Al-Ansari, "Water Resources in the Arab Countries: Problems and Possible Solutions," UNESCO International Conference (Water: A Looming Crisis), Paris, 3-6 June 1998, pp. 367-376.

[2] N. A. Al-Ansari and S. Knutsson, "Toward Prudent Management of Water Resources in Iraq," Journal of Advanced Science and Engineering Research, Vol. 1, 2011, pp. 53-67.

[3] N. A. Al-Ansari, "Management of Water Resources in Iraq: Perspectives and Prognoses,” Engineering, Vol. 5, No. 8, 2013, pp. 667-684.

http://dx.doi.org/10.4236/eng.2013.58080

[4] N. A. Al-Ansari, E. Salameh and I. Al-Omari, "Analysis of Rainfall in the Badia Region, Jordan,” Al-Bayt University Research Paper No.1, 1999, 66 p.

[5] A. Hamdy, "Water Crisis and Food Security in the Arab World: The Future Challenges," 2013.

http://gwpmed.org/files/IWRM-Libya/Atef\%20Hamdy\% 20AWC.pdf

[6] United Nations, "Water Resources Management White Paper," United Nations Assistance Mission for Iraq, United Nations Country Team in Iraq, 2010, 20 p. http://iq.one.un.org/documents/100/white\%20paper-eng_ Small.pdf

[7] N. A. Al-Ansari, H. I. Assaid and V. N. Salim, "Water Resources in Iraq," Journal of the Geological Society, Vol. 15, 1981, pp. 35-42.
[8] FAO, "Water Profile of Iraq," 2008. http://www.eoearth.org/view/article/51cbef2d7896bb431f 69ceb3/

[9] D. Prinz, "The Role of Water Harvesting in Alleviating Water Scarcity in Arid Areas," Keynote Lecture, Proceedings of International Conference on Water Resources Management in Arid Regions, Vol. III, Kuwait, Kuwait Institute for Scientific Research, 23-27 March 2002, pp. 107-122.

[10] J. Chenoweth, P. Hadjinicolaou, A. Bruggeman, J. Lelieveld, Z. Levin, M. Lange, E. Xoplaki and M. Hadjikakoul, "Impact of Climate Change on the Water Resources of the Eastern Mediterranean and Middle East Region: Modeled 21st Century Changes and Implications,” Journal of Water Resources Research, Vol. 47, 2011, Article ID: W06506, pp. 1-18.

[11] K. Voss, J. Famiglietti, M. Lo, C. de Linage, M. Rodell and S. Swenson, "Groundwater Depletion in the Middle East from GRACE with Implications for Transboundary Water Management in the Tigris-Euphrates-Western Iran Region," Water Resources Research, Vol. 49, No. 2, 2013, pp. 904-914. http://dx.doi.org/10.1002/wrcr.20078

[12] D. Prinz and A. K. Singh, "Water Resources in Arid Regions and Their Sustainable Management. Special Issue on Research,” Annals of Arid Zone, Vol. 39, No. 3, 2000, pp. 1-8.

[13] T. Naff, "Conflict and Water Use in the Middle East,” In: R. Roger and P. Lydon, Eds., Water in the Arab Word: Perspectives and Prognoses, Harvard University, 1993, pp. 253-284.

[14] N. A. Al-Ansari, “Applied Surface Hydrology,” Al-Bayt University Publication, Mafraq, 2005.

[15] K. Shideed, T. Oweis and E. Mohammad, "Enhancing Agricultural Productivity through On-Farm Water-Use Efficiency: An Empirical Case Study of Wheat Production in Iraq,” ESCWA/SDPD, New York, 2003, p. 15.

[16] K. K. Gupta, J. Deelstra and K. D. Sharma, "Estimation of Water Harvesting Potential for a Semiarid Area Using GIS and Remote Sensing, Remote Sensing and Geographic Information System for Design and Operation of Water Resources System,” Proceedings of Information Symposium, Rabat, Vol. 242, 1997, pp. 53-62.

[17] S. Nasri, A. Jean, C. Christophe and B. Ronny, "Hydrological Processes in Macro Catchment Water Harvesting in the Arid Region of Tunisia: The Traditional System of Tabias,” Journal of Hydrological Sciences, Vol. 49, No. 2, 2004, pp. 261-272. http://dx.doi.org/10.1623/hysj.49.2.261.34838

[18] T. Oweis, A. Hachum and J. Kijne, "Water Harvesting and Supplemental Irrigation for Improved Water Use Efficiency in Dry Areas,” International Water Management Institute, Colombo, 1999, $41 \mathrm{p}$. http://www.iwmi.cgiar.org/Publications/SWIM_Papers/P DFs/Swim07.pdf

[19] C. Reij, P. Mulder and L. Begemann, "Water Harvesting for Plant Production,” World Bank Technical Paper, Washington DC, 1988, p. 4.

[20] Th. M. Boers and J. Ben-Asher, "A Review of Rainwater Harvesting,” Agricultural Water Management, Vol. 5, No. 
2, 1982, pp. $145-158$. http://dx.doi.org/10.1016/0378-3774(82)90003-8

[21] H. J. Finkel and M. Finkel, "Engineering Measures: Water Harvesting,” In: H. J. Finkel, M. Finkel and Z. Naveh, Eds., Semi-Arid Soil and Water Conservation, CRC Press, Inc., Boca Raton, 1986, pp. 93-101.

[22] K. Siegert, "Introduction to Water Harvesting. Some Basic Principles for Planning, Designand Monitoring," In: FAO, Water Harvesting For Improved Agricultural Production. Expert Consultation, Cairo, 21-25 November 1994, pp. 9-23.

http://www.fao.org/docrep/u3160e/u3160e03.htm\#1.2defi nitionsandclassification

[23] D. Prinz, "Water Harvesting: Past and Future,” In: L. S. Pereira, Ed., Proceedings of Sustainability of Irrigated Agriculture, NATO Advanced Research Workshop, Rotterdam, 1996, pp. 135-144.

[24] S. Zakaria, N. A. Al-Ansari, S. Knutsson and M. EzzAldeen, "Rain Water Harvesting and Supplemental Irrigation at Northern Sinjar Mountain, Iraq," Journal of Purity, Utility Reaction and Environment, Vol. 1, No. 3, 2012, pp. 121-141.

[25] S. Zakaria, N. A. Al-Ansari, S. Knutsson and M. EzzAldeen, "Rain Water Harvesting at Eastern Sinjar Mountain, Iraq,” Journal of Geoscience Research, Vol. 3, No. 2, 2012, pp. 100-108.

[26] S. Zakaria, N. A. Al-Ansari and S. Knutsson, "Rainwater Harvesting Using Recorded and Hypothetical Rainfall Data Scenarios,” Journal of Earth Sciences and Geotechnical Engineering, Vol. 3, No. 2, 2013, pp. 21-42.

[27] N. A. Al-Ansari, M. Ezz-Aldeen, S. Knutsson and S. Zakaria, "Water Harvesting and Reservoir Optimization in Selected Areas of South Sinjar Mountain, Iraq,” Journal of Hydrologic Engineering, 2013.

[28] J. Anschütz, A. Kome, M. Nederlof, R. de Neef and T. van de Ven, "Water Harvesting and Soil Moisture Retention,” 2nd Edition, Stoas Digigrafi, Wageningen, 2003.

[29] A. H. Bakari, H. F. Mahoo and N. Hatibu, "Perormance of Maize under Gully Flow Supplementary Irrigation,” In: P. J. Makungu, H. F. Mahoo, V. C. K. Silayo and M. Mdemu, Eds., Proceedings of Tanzania Society of Agricultural Engineers, Vol. 8, 1998, pp. 20-42.

[30] J. W. Gowing, H. F. Mahoo, O. B. Mzirai and N. Hatibu, "Review of Water Harvesting Techniques and Evidence for Their Use in Semi-Arid Tanzania,” Tanzania Journal of Agricultural Science, Vol. 2, No. 2, 1999, pp. 171-180.

[31] O. Mzirai and S. Tumbo, "Macro-Catchment Rainwater Harvesting Systems: Challenges and Opportunities to Access Runoff,” Journal of Animal \& Plant Sciences, Vol. 7, No. 2, 2010, pp. 789-800.

[32] H. J. Bruins, M. Evenari and U. Nessler, "RainwaterHarvesting Agriculture for Food Production in Arid Zones the Challenge of the African Famine," Applied Geography, Vol. 6, No. 1, 1986, pp. 13-32. http://dx.doi.org/10.1016/0143-6228(86)90026-3

[33] P. Fox and J. Rockstrom, "Supplemental Irrigation for DrySpell Mitigation of Rainfed Agriculture in the Sahel," Agricultural Water Management, Vol. 61, No. 1, 2003, pp. 29-50.

http://dx.doi.org/10.1016/S0378-3774(03)00008-8

[34] N. Hatibu, M. D. B. Young, J. W. Gowing, H. F. Mahoo and O. B. Mzirai, "Developing Improved Dryland Cropping Systems for Maize in Semi-Arid Tanzania. Part 1: Experimental Evidence for the Benefits of Rainwater Harvesting," Experimental Agriculture, Vol. 39, No. 3, 2003, pp. 279-292.

http://dx.doi.org/10.1017/S0014479703001285

[35] K. E. Motsi, E. Chuma and B. B. Mukamuri, "Rainwater Harvesting for Sustainable Agriculture in Communal Lands of Zimbabwe," Physics and Chemistry of the Earth, Vol. 29, No. 15-18, 2004, pp. 1069-1073.

[36] J. Barron and G. Okwach, "Run-Off Water Harvesting for Dry Spell Mitigation in Maize (Zea mays L.): Results from On-Farm Research in Semi-Arid Kenya,” Agricultural Water Management, Vol. 74, No. 1, 2005, pp. 1-21. http://dx.doi.org/10.1016/j.agwat.2004.11.002

[37] F. Liu, Y. Wu, H. Xiao and Q. Gao, "Rainwater-Harvesting Agriculture and Water Use Efficiency in Semi-Arid Regions in Gansu Province, China," Outlook on Agriculture, Vol. 34, No. 3, 2005, pp. 159-165. http://dx.doi.org/10.5367/000000005774378838

[38] K. O. Adekalu, J. A. Balogun, O. B. Aluko, D. A. Okunade, J. W. Gowing and M. O. Faborode, "Runoff Water Harvesting for Dry Spell Mitigation for Cowpea in the Savannah Belt of Nigeria,” Agricultural Water Management, Vol. 96, No. 11, 2009, pp. 1502-1508.

http://dx.doi.org/10.1016/j.agwat.2009.06.005

[39] N. Hatibu and H. Mahoo, "Rainwater Harvesting Technologies for Agricultural Production: A Case for Dodoma, Tanzania,” In: P. G. Kaumbutho and T. E. Simalenga, Eds., Conservation Tillage with Animal Traction. A Resource Book of the Animal Traction Network for Eastern and Southern Africa, ATNESA, Harare, 1999, 173 p.

[40] J. Rockstrom, L. Karlberg, S. P. Wani, J. Barron, N. Hatibu, T. Oweis, A. Bruggeman, J. Farahani and Q. Zhu, "Managing Water in Rainfed Agriculture. The Need for a Paradigm Shift," Agricultural Water Management, Vol. 97, 2010, pp. 543-550.

[41] T. Oweis and A. Hachum, "Water Harvesting for Agriculture in Dry Areas,” CRC Press, Balkema, 2012, p. 57. http://dx.doi.org/10.1016/S0378-3774(01)00096-8

[42] V. T. Chow, D. R. Maidment and L. W. Mays, “Applied Hydrology,” McGraw Hill, New York, 1988, pp. 147151.

[43] J. R. Williams, “The EPIC Model, Chapter 25,” In: V. P. Singh, Ed., Computer Models of Watershed Hydrology, Water Resources Publications, Highlands Ranch, 1995.

[44] S. L. Neitsch, J. G. Arnold, J. R. Kiniry and J. R. Williams, "Soil and Water Assessments Tool Theoretical Documentation,” 2005, p. 102.

http://swat.tamu.edu/media/1292/swat2005theory.pdf

[45] ASCE, “ASCE/EWRI Curve Number Hydrology Task Committee,” In: R. H. Hawkins, T. J. Ward, E. W. Donald and J. A. Van Mullem, Eds., Curve Number Hydrology: State of the Practice, American Society of Civil Engineers, Reston, 2009, 116 p.

[46] H. Mohammed, "Water Harvesting in Erbil Governorate, 
Kurdistan Region, Iraq. Detection of Suitable Sites Using Geographic Information System and Remote Sensing,” Master Thesis, Lund University, 2013, 13 p.

[47] P. Buringh, "Soils and Soil Conditions of Iraq," Ministry of Agriculture, Agricultural Research and Projects, Baghdad, 1960.
[48] S. Zakaria, N. A. Al-Ansari, Y. Mustafa, S. Knutsson, P. Ahmad and B. Ghafour, "Rainwater Harvesting at Koysinjaq (Koya), Kurdistan Region, Iraq,” Journal of Earth Sciences and Geotechnical Engineering, 2013. 